\title{
Analisis Compressive Stress pada Paving Block Tipe Grass Berbahan Sampah Plastik
}

\author{
Rolan Siregar ${ }^{1, a)}$, Ady Anggoro ${ }^{2)}$, Asyari Darius ${ }^{3)}$, Yefri Chan ${ }^{4)}$, Husen Asbanu ${ }^{5)}$, dan \\ Nurhasanah $\left.^{6}\right)$
}

\author{
1, 2, 3, 4, 5, 6)Program Studi Teknik Mesin Universitas Darma Persada, \\ J1. Taman Malaka Selatan No.22, Pondok Kelapa, Kec. Duren Sawit, Kota Jakarta Timur, \\ DKI Jakarta, Indonesia, 13450 \\ a) rolansiregar@ft.unsada.ac.id (corresponding author)
}

\begin{abstract}
Abstrak
Indonesia adalah salah satu penghasil sampah plastik yang paling banyak sehingga hal ini berdampak buruk bagi masyarakat seperti polusi air dan potensi banjir. Penelitian ini berperan penting dalam mengurangi dampak buruk tersebut melalui pengolahan sampah plastik menjadi paving block. Tujuan khusus dalam penelitian ini adalah untuk mengetahui lama pemanasan sampah plastik yang paling optimal dalam sebuah mesin cetak paving block dan untuk mengetahui nilai tegangan tekan (compressive stress) pada paving block yang dihasilkan tersebut. Paving block yang dibuat sesuai dengan standar SNI yaitu tipe grass lubang lima dengan ukuran panjang $40 \mathrm{~cm}$, lebar $40 \mathrm{~cm}$, dan tebal $8 \mathrm{~cm}$. Secara keseluruhan metode dalam penelitian ini adalah metode eksperimental yang dikerjakan dengan tahapan yang sistematis. Dari hasil penelitian diperoleh lama pemanasan yang paling optimal adalah 40 menit dan nilai compressive stress adalah 18,83 MPa. Berdasarkan standar SNI tegangan tekan paving block adalah antara 9,8 s.d. 39,2 MPa, maka paving block yang dicetak tersebut sudah berada dalam rentang aman. Oleh karena itu penelitian ini diharapkan bermanfaat untuk pengembangan teknologi pengolahan sampah plastik menjadi produk paving block.
\end{abstract}

Kata kunci: sampah plastik, paving block, grass block, pencemaran lingkungan, compressive stress.

\begin{abstract}
Indonesia is one of the biggest producers of plastic waste, so this has a negative impact on the community such as water pollution and potential flooding. This research is important in reducing these adverse effects through processing plastic waste into paving blocks. The specific purpose of this research is to find out the optimal heating time of plastic waste in a paving block molding machine and to determine the compressive stress value of the resulting paving block. Paving blocks that are made in accordance with SNI standards are a type of grass hole five with a length of $40 \mathrm{~cm}$, width $40 \mathrm{~cm}$ and thickness of $8 \mathrm{~cm}$. Overall the method in this study is an experimental method that is worked out with systematic steps. From the research results, the optimal heating time is 40 minutes and the compressive stress value is $18.83 \mathrm{MPa}$. Based on the SNI standard the compressive stress of paving blocks is between 9.8 s.d. $39.2 \mathrm{MPa}$, the paving blocks that are made are already within the safe range. Therefore this research is expected to be useful for the development of technology for processing plastic waste into paving block products.
\end{abstract}

Keywords: plastic waste, paving blocks, grass blocks, environmental pollution, compressive stress.

\section{PENDAHULUAN}

Pengolahan sampah plastik menjadi paving block adalah salah satu cara untuk mengurangi pencemaran lingkungan akibat sampah plastik. Pengolahan ini menjadi penting untuk segera dikembangkan di Indonesia karena jumlah sampah yang dihasilkan oleh masyarakat maupun industri sangat besar yang dapat menimbulkan masalah yang serius seperti banjir. Indonesia adalah salah satu negara penghasil sampah plastik terbanyak ke laut setelah Tiongkok [1]. Oleh karena itu pengelolaan sampah adalah upaya yang harus dilakukan bersama untuk menanggulangi pencemaran lingkungan [2]. Pada penelitian ini akan membahas pemanfaatan sampah plastik menjadi sebuah produk yaitu paving block tipe grass atau sering disingkat grass block. Dengan mempertimbangkan dampak sampah plastik terhadap pencemaran lingkungan beserta banjir di berbagai daerah di Indonesia maka penelitian ini sangat penting untuk dituntaskan dalam rangka pengurangan pencemaran lingkungan akibat sampah plastik tersebut. Paving block biasa digunakan pada area lintasan untuk menghindari terjadinya lumpur, kesesuaian estetika, dan kemudahan untuk dibersihkan seperti halaman rumah, trotoar pejalan kaki, petamanan, dan parkir mobil. Grass block adalah paving block yang memiliki ruang untuk pertumbuhan rumput dan sekaligus resapan air. Grass block yang didesain adalah grass block berlubang lima dengan ukuran Standar Nasional Indonesia. Mesin press grass block didesain dengan konsep pemanfaatan suhu elemen heater untuk meleburkan plastik dan diikuti oleh penekanan dari elemen press sehingga diperoleh balok plastik yang padat dengan bentuk sesuai cetakan.

Sebagai masalah utama dalam penelitian ini adalah bagaimana kekuatan konstruksi grass block berbahan 
sampah plastik yang berbeda-beda tipe dari tempat pembuangan sampah. Tujuan khusus penelitian ini adalah untuk mengetahui kekuatan struktur grass block berbahan sampah plastik dan untuk mengetahui lama pemanasan yang paling optimal. Penelitian ini diharapkan akan menjadi solusi alternatif pengolahan sampah plastik karena proses pembuatan yang relatif mudah dan dapat diterapkan di seluruh wilayah tempat pembuangan akhir (TPA) sampah Indonesia.

\section{LANDASAN TEORI}

\section{A. Studi Pengembangan dan Problem Statement}

Penelitian tentang pembuatan paving block berbahan sampah plastik mulai dikembangkan oleh beberapa peneliti terdahulu karena masalah lingkungan yang timbul akibat sampah yang terus meningkat. Dalam artikel Pattnaik dkk. (2015)[3] dan Nishikant dkk. (2016)[4] menyajikan tentang pembuatan paving block berbahan tepung gelas (powder glass), di dalam penelitian ini menampilkan paving block tipe solid dengan bahan yang divariasikan dengan berbagai bahan semen. Perkiraan potensi pengembangan paving block ini kurang signifikan karena terkait dengan ketersediaan bahan mentah dan efesiensi harga. Hal yang mirip dalam penelitian Gencel dkk. (2012) [5] tentang pembuatan paving block berbahan marmer (marble), produk ini akan menjadi paving block yang relatif mahal. Pengembangan lainnya adalah dalam penelitian Yeole dan Varma (2014)[6] di mana paving block dibuat dari sampah olahan baja dan karet, dalam produk ini ditampilkan sebuah paving block yang relatif rumit untuk diproduksi. Selain itu kajian yang dilakukan Pawar dan Arthmwar (2018) [7] menampilkan perbedaan kekuatan tekan paving block konvensional dengan paving block berbahan variasi sampah dengan hasil bahwa adanya indikasi peningkatan kekuatan tekan dalam paving block hasil campuran sampah tertentu seperti karet dalam porsi yang ideal. Selanjutnya artikel Shanmugavalli dkk. (2017)[8] menampilkan penggunaan sampah plastik menjadi paving block, dalam riset ini ditampilkan paving block tipe solid dengan proses pemanasan plastik dengan api dan tipe plastik yang seragam, dalam penelitian ini belum menampilkan sebuah teknologi dalam proses pembuatan paving block tersebut. Dari semua penelitian yang telah ditinjau bahwa penggunaan berbagai sampah menjadi sebuah paving block memiliki potensi yang sangat besar, di mana sebuah hasil yang optimal bergantung ke pada proses pembuatan. Namun dalam beberapa kajian penelitian tersebut belum ada menampilkan sebuah paving block tipe grass dengan teknonologi mesin pencetakan yang spesifik. Maka dalam penelitian ini akan ditampilkan sebuah paving block tipe grass berbahan sampah plastik yang bervariasi beserta nilai kekuatan tekan benda tersebut. Grass block akan menjadi sebuah paving block yang paling sesuai jika berbahan plastik yang ditempatkan dalam taman atau daerah jelajah karena memiliki ruang serapan air beserta tempat bertumbuhnya rumput dan sekaligus menambah estetika lingkungan.

\section{B. Konsep Desain Mesin Press Paving Block}

Pada penelitian ini akan dibahas tentang produksi paving block tipe grass berlubang lima sehingga daya serap air tidak terganggu. Berdasarkan standar SNI 030691-1996 bahwa paving block diklasifikasikan berdasarkan kegunaannya yaitu pengerasan jalan, tempat parkir mobil, untuk pejalan kaki, untuk taman kota. Berdasarkan bentuknya paving block dibagi menjadi dua yaitu solid (paving block) dan porous (grass block). Maka sebagai acuan pengembangan adalah grass block berlubang lima dengan Standar SNI dengan ukuran panjang $40 \mathrm{~cm}$, lebar $40 \mathrm{~cm}$, dan tebal $8 \mathrm{~cm}$ seperti yang ditunjukkan pada Gambar 1.

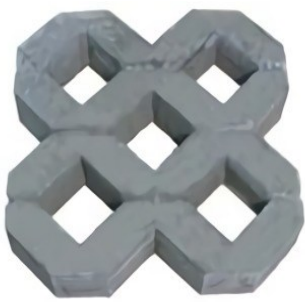

Gambar 1. Bentuk grass block bahan semen [9]

Pengembangan mesin produksi grass block dibuat dengan mengacu pada ukuran tersebut dalam bentuk prototipe. Mesin press paving block ini memiliki konsep desain yang relatif kompleks yaitu dengan memanfaatkan temperatur dari elemen heater yang ada dalam cetakan beserta bantuan pemanas dari luar yaitu api gas LPG. Pemanas ini digunakan untuk meleburkan plastik di mana temperatur dalam ruang pemanas dapat dikontrol dengan menggunakan thermostat. Pada Gambar 2 berikut ditampilkan desain mesin press paving block.

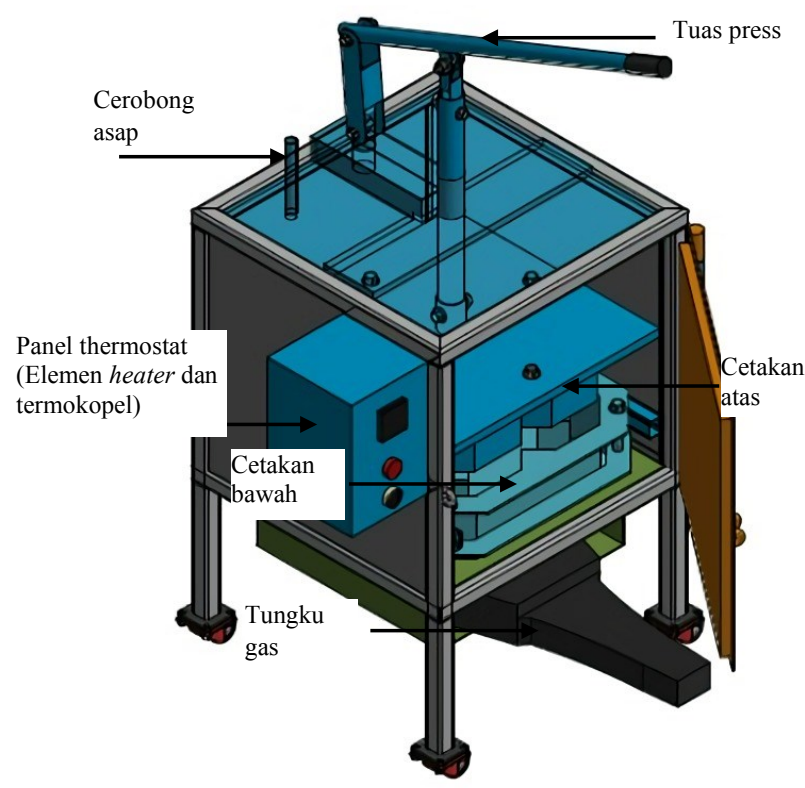

Gambar 2. Konsep desain mesin press paving block bahan sampah plastik

Seperti ditunjukkan pada Gambar 2, dapat dijelaskan bahwa tungku gas berfungsi sebagai pemanas cetakan dari luar. Panel thermostat digunakan sebagai alat pengatur suhu elemen heater yang direkatkan dalam cetakan beserta display temperatur dalam cetakan. Cetakan bawah dan cetakan atas dibuat sesuai bentuk grass blok dengan ukuran Standar Nasional Indonesia (SNI) dengan lima 
lubang. Cerobong asap berfungsi sebagai ruang sirkulasi untuk mengurangi tekanan akibat termal dalam ruang pemanas. Tuas press digunakan sebagai penekan manual dan pengangkat cetakan atas ketika akan mengambil hasil cetakan. Penekanan pada plastik dalam cetakan dilakukan untuk mengurangi gelembung udara dalam paving block ketika pemanasan sedang terjadi. Adapun besar tekanan terdiri dari berat sendiri cetakan atas beserta tekanan luar yang diberikan pada tuas. Untuk lebih jelas dapat dilihat pada Gambar 3 berikut.

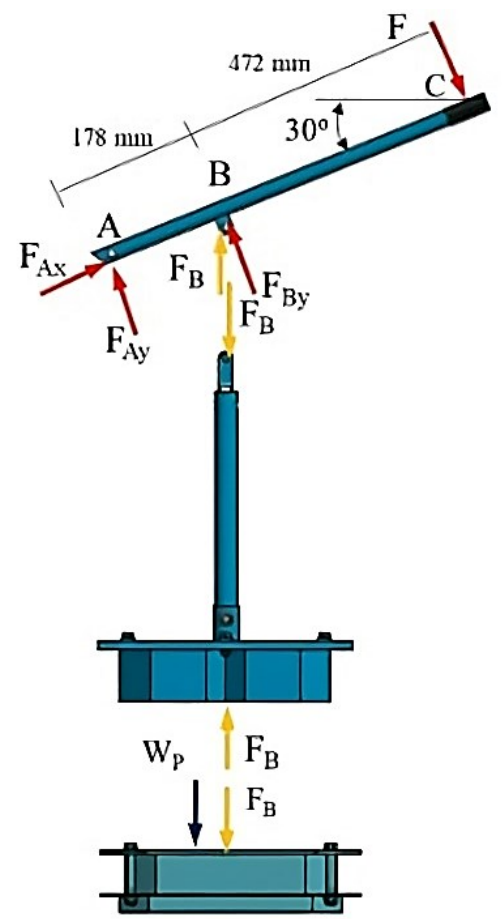

Gambar 3. Gaya yang bekerja dalam cetakan

Adapun perkiraan besar tekanan pada cetakan bawah adalah sebagaimana persamaan 1 .

$$
P=\frac{F_{B}+W_{P}}{A}
$$

Di mana $F_{B}$ adalah gaya yang diteruskan ke cetakan dari gaya tekan luar $(\mathrm{N})$. $\mathrm{W}_{\mathrm{P}}$ adalah gaya gaya dari berat cetakan atas sendiri $(\mathrm{N})$. A adalah luas permukaan sentuh pada cetakan bawah $\left(\mathrm{m}^{2}\right)$.

\section{METODE PENELITIAN/EKSPERIMEN}

Metode dalam penelitian ini adalah eksperimental di mana tahapan pelaksanaan dibuat dalam tahapan yang sistematis. Secara keseluruhan tahapan penelitian ini dapat dilihat pada diagram alir yang ditunjukkan dalam Gambar 4.

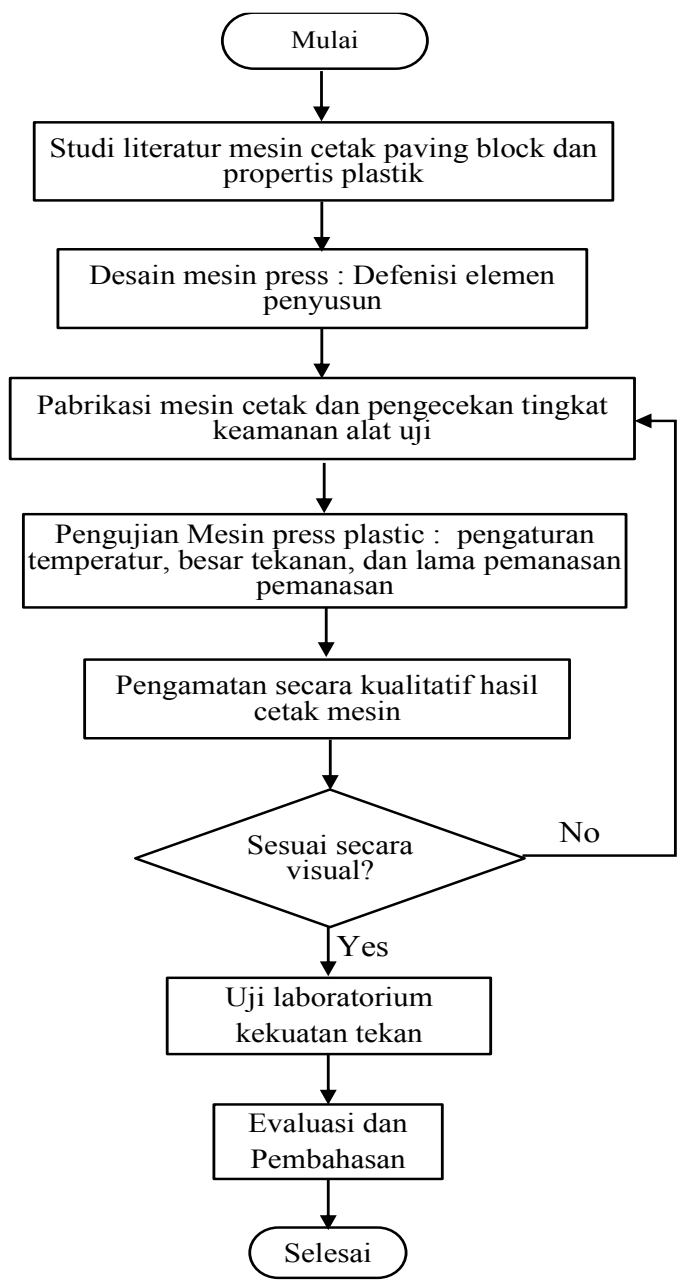

Gambar 4. Tahapan pelaksanaan riset

Secara umum metode yang digunakan untuk mencapai tujuan adalah eksperimental. Tahap awal membuat kerangka mesin adalah dengan membuat desain dalam bentuk CAD supaya mudah direvisi untuk mencapai hasil terbaik sebelum dipabrikasi[10][11]. Setelah mesin dibuat maka tahapan berikutnya adalah pengujian pencetakan paving block. Pengujian dilakukan sampai diperoleh paving block terbaik secara visual dan diakhiri dengan pengujian tegangan tekan (compressive stress) untuk mengetahui sifat mekanik benda uji tersebut. Hasil pengujian menjadi data untuk mendukung pengembangan paving block berbahan sampah plastik yang siap untuk diproduksi massal. Set up pengujian dapat dilihat pada Gambar 5 berikut.

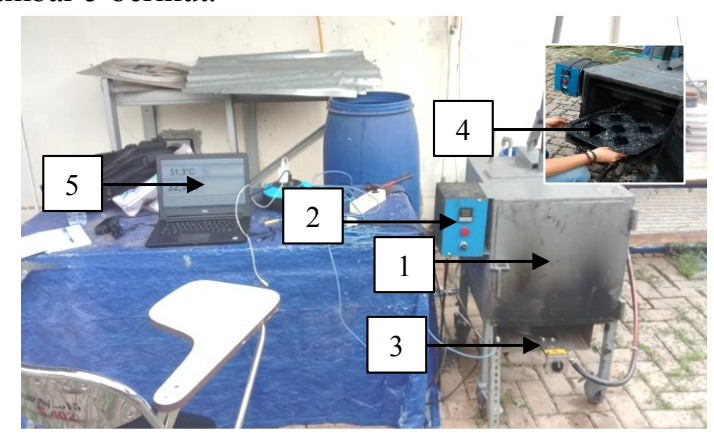

Gambar 5. Set up proses pencetakan grass block 
Beberapa elemen utama dalam mesin press plastik ini yaitu nomor 1 adalah ruang pemanas, nomor 2 sebagai pengatur elemen heater untuk menentukan batas temperatur dalam ruang cetakan, nomor 3 sebagai pemanas tambahan luar dengan bahan bakas gas, nomor 4 adalah bentuk cetakan yang diisi sampah plastik tipe termoplastik yang telah dicacah, dan nomor 5 adalah monitor sekaligus data logger untuk menyimpan data lama pemanasan mencapai temperatur yang diinginkan.

Spesimen yang dilakukan pengujian tegangan tekan adalah spesimen yang terbaik secara visual seperti kepadatan dan kerataan plastik yang melebur. Adapun alat uji yang dilakukan adalah alat uji tekan beton berkapasitas 180.000 kgf seperti pada Gambar 6 .
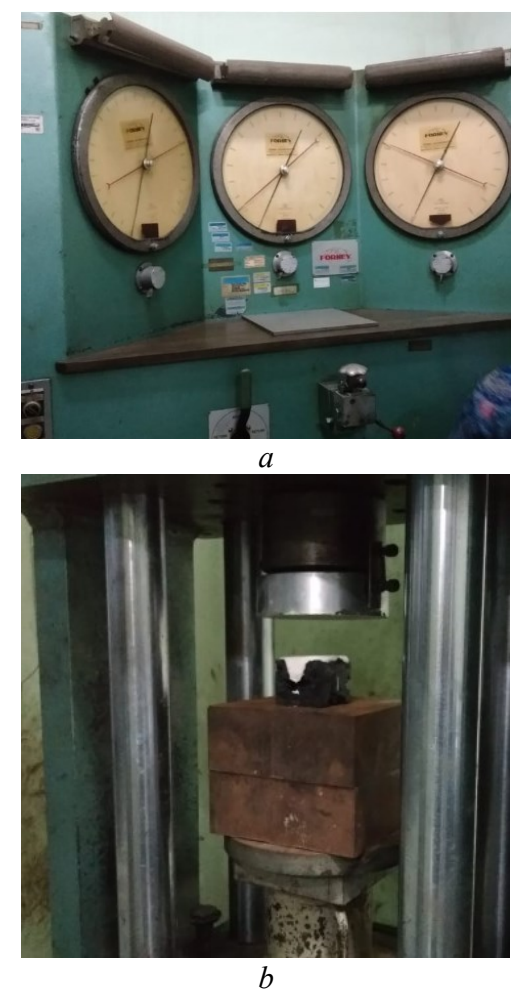

Gambar 6. Uji compressive stress paving block: $a$ - display; $b$ posisi spesimen uji

Secara umum perhitungan compressive stress paving block dapat dihitung dengan Persamaan 2.

$$
\sigma=\frac{P}{A}
$$

di mana $\sigma$ adalah tegangan tekan $(\mathrm{Pa}), \mathrm{P}$ adalah gaya tekan mesin uji (N) dan A adalah luas permukaan sentuh paving block $\left(\mathrm{m}^{2}\right)$. Paving block dipotong sesuai dengan ukura standar pengujian laboratorium dengan permukaan harus rata sehingga ada penambahan benda perata standar laboratorium. Adapun ukuran spesimen uji tekan adalah panjang $10 \mathrm{~cm}$, lebar $10 \mathrm{~cm}$, dan tebal $8 \mathrm{~cm}$. Uji tekan dilakukan dalam suhu ruangan $27^{\circ} \mathrm{C}$.

\section{HASIL DAN PEMBAHASAN}

Hasil pengujian paving block tipe grass lubang lima dibuat sesuai ukuran standar SNI (40 cm x $40 \mathrm{~cm}$ x $8 \mathrm{~cm}$ ). Temperatur pemanasan dalam ruang cetakan mengacu pada penelitian sebelumnya yaitu $200{ }^{\circ} \mathrm{C}[12]$. Selanjutnya variasi temperatur diberikan untuk lima kali pengujian pencetakan yaitu 20 menit, 25 menit, 30 menit, 35 menit, dan 40 menit. Untuk lebih jelasnya hasil cetakan dapat dilihat pada Tabel 1 berikut.

Tabel 1. Grass Block Berbahan Sampah Plastik

\begin{tabular}{|c|c|c|c|}
\hline No & $\begin{array}{l}\text { Temprature } \\
\left({ }^{\circ} \mathbf{C}\right)\end{array}$ & $\begin{array}{l}\text { Time } \\
\text { (menit) }\end{array}$ & Foto \\
\hline 1 & $200^{\circ} \mathrm{C}$ & 20 & \\
\hline 2 & $200^{\circ} \mathrm{C}$ & 25 & \\
\hline 3 & $200^{\circ} \mathrm{C}$ & 30 & \\
\hline 4 & $200^{\circ} \mathrm{C}$ & 35 & \\
\hline 5 & $200^{\circ} \mathrm{C}$ & 40 & \\
\hline
\end{tabular}

Tabel 1 menunjukkan bahwa temperatur yang digunakan adalah $200{ }^{\circ} \mathrm{C}$ sesuai dengan pendekatan yang dilakukan pada penelitian terdahulu [12]. Selanjutnya lama pemanasan divariasikan dengan beda waktu lima menit untuk mendapatkan kualitas cetakan yang terbaik. Hasil pencetakan grass block tersebut menunjukkan bahwa pengujian dengan lama pemanasan 40 menit adalah kualitas terbaik. Hasil ini diperoleh berdasarkan hasil visualisasi seperti kepadatan dan kerataan permukaan. Hasil visualisasi benda uji lainnya menunjukkan adanya peleburan yang belum sempurna dan terdapat ruang-ruang kosong atau cacat volume seperti pada Gambar 7 sehingga benda tersebut dipastikan lebih rapuh sehingga tidak dilakukan uji tekan . 


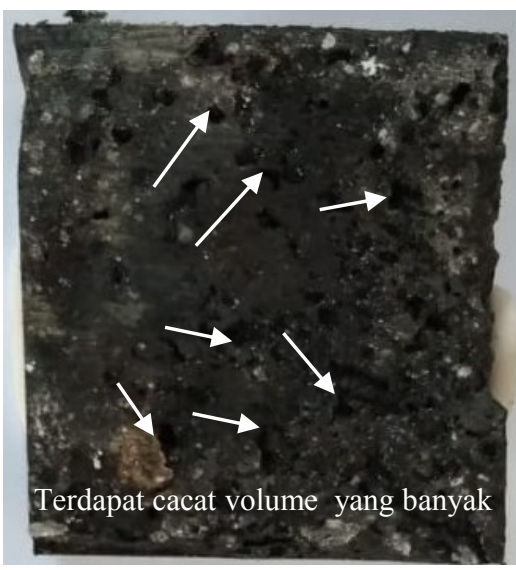

Gambar 7. Contoh cacat volume spesimen

Cacat volume tersebut diperkirakan karena adanya gelembung udara di bagian tertentu karena plastik belum melebur sempurna. Spesimen yang dilakukan uji tekan (compressive stress) adalah paving block yang terbaik yaitu dari lama pemanasan 40 menit yaitu hasil pengujian nomor lima. Uji tekan ini dilakukan di Laboratorium Unit Industri Bahan dan Barang Teknik Dinas Perindustrian dan Energi DKI Jakarta. Pada Gambar 8 berikut ditampilkan hasil uji tekan grass block.

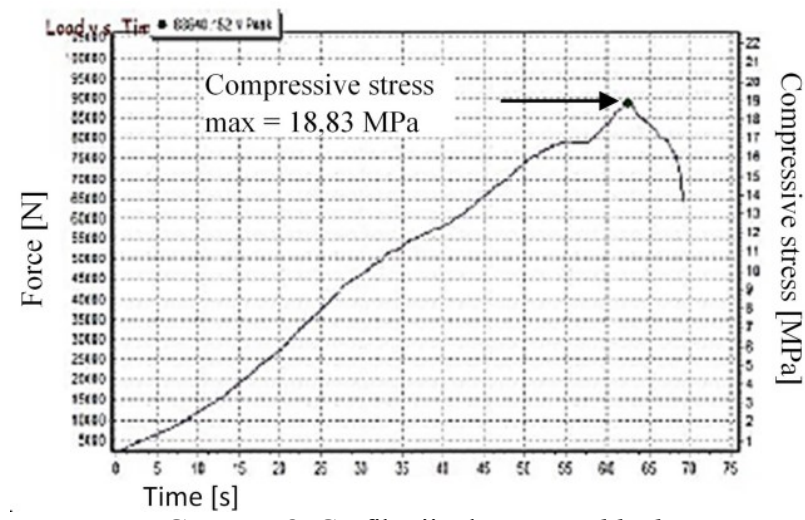

Gambar 8. Grafik uji tekan grass block

Berdasarkan uji tekan yang dilakukan diperoleh hasil tegangan tekan (compressive stress) sebesar 18,83 N/mm² $=18,83 \mathrm{MPa}$. Berdasarkan standar SNI besar tegangan tekan paving block adalah sekitar 9.8 - 39.2 MPa semakin tinggi tegangan tekan maka kualitas produk semakin baik. Maka paving block yang dibuat sudah memasuki rentang SNI dengan kualitas menengah.

\section{KESIMPULAN}

Sebagai kesimpulan dalam penelitian ini adalah besar tegangan tekan (compressive stress) pada paving block yang dihasilkan adalah $18,83 \mathrm{MPa}$ pada pemanasan $200^{\circ} \mathrm{C}$ dengan lama pemanasan 40 menit. Nilai ini sudah berada dalam standar SNI yaitu antara 9,8 s.d. 39,2 MPa dengan kategori mutu menengah. Perlu dilakukan penelitian yang lebih lanjut untuk mendapatkan tegangan tekan yang lebih tinggi di mana tipe grass block menjadi salah satu pilihan kajian terbaik dengan pertimbangan tidak memgganggu penyerapan air ke dalam tanah. Maka penelitian ini memiliki potensi yang sangat besar sebagai solusi alternatif dalam pengurangan pencemaran sampah plastik. UCAPAN TERIMA KASIH

Penulis mengucapkan terima kasih yang sebesarbesarnya kepada LP2MK beserta jajaran pimpinan Universitas Darma Persada yang telah membantu dana penelitian ini melalui hibah riset dosen tetap Semester Ganjil TA 2019-2020.

\section{REFERENSI}

[1] S. Puspita and E. Patnistik, "Indonesia Penyumbang Sampah Plastik Terbesar Kedua di Dunia," 2018. [Online]. Available: https://megapolitan.kompas.com/read/2018/08/19/2115 1811/indonesia-penyumbang-sampah-plastik-terbesarkedua-di-dunia. [Accessed: 16-Feb-2020].

[2] Wanda, "Upaya Indonesia Menanggulangi Limbah Sampah Plastik Dari Belanda," Jom Fisip, vol. 6, no. 1, pp. 1-12, 2019.

[3] T. Pattnaik, R. Mohanta, N, N. Patel, P. Biswal, and R. . Moharana, "Manufacture of interlocking concrete paving blocks with fly ash and glass powder," Int. J. Civ. Eng. Technol., vol. 6, no. 4, pp. 55-64, 2015.

[4] K. Nishikant, A. Nachiket, I. Avadhut, and A. Sangar, "Manufacturing of Concrete Paving Block by Using Waste Glass Material," Int. J. Sci. Res. Publ., vol. 6, no. 6, pp. 61-77, 2016.

[5] O. Gencel, C. Ozel, F. Koksal, E. Erdogmus, G. Martínez-Barrera, and W. Brostow, "Properties of concrete paving blocks made with waste marble," $J$. Clean. Prod., vol. 21, no. 1, pp. 62-70, 2012.

[6] R. C. Yeole and M. B. Varma, "Comparison of Mix Designs of Paver Blocks using Waste Rounded Steel Aggregates and Rubber Pad," Int. J. Emerg. Technol. Adv. Eng., vol. 4, no. 10, pp. 523-527, 2014.

[7] S. Pawar, S. Sangde, A. Shinde, S. Patil, A. Patil, and S. Arthmwar, "Comparision of Paver Block Made From Various Wastage to the Conventional Paver Block," IRJET, pp. 3634-3635, 2018.

[8] B. Shanmugavalli, K. Gowtham, P. Jeba Nalwin, and B. Eswara Moorthy, "Reuse of Plastic Waste in Paver Blocks," Int. J. Eng. Res. Technol., vol. V6, no. 02, pp. 313-315, 2017.

[9] Rani, "Harga Grass Block Tahun 2019," Rani Block, 2019. [Online]. Available: http://pavingblockindonesia.com/harga-grass-block/. [Accessed: 24-Feb-2020].

[10] R. Siregar, M. Bur, and S. Huda, "Perkiraan Kekuatan Struktur Mekanik Side Scraper dengan Metode Elemen Hingga Beserta Rekomendasi Material Pengganti Elemen Kritis," ROTASI, vol. 21, no. 4, pp. 251-257, 2019.

[11] R. Siregar, F. Zainuri, and M. Adhitya, "Design a New Generation of Synchromesh Mechanism to Optimization Manual Transmission's Electric Vehicle," in Proceeding of the 15th International Conference on QIR (Quality in Research) ISSN, 2017, vol. 1411, p. 1284.

[12] R. Siregar, "Korelasi Besar Temperatur Pemanasan Cetakan terhadap Kualitas Hasil Press Paving Block Berbahan Dasar Sampah Plastik," FLYWHEEL J. Tek. Mesin Untirta, vol. V, no. 1, pp. 41-45, 2019. 